\title{
Two-stage commercial evaluation of engineering systems production projects for high-rise buildings
}

\author{
Aleksander Bril ${ }^{1}$, Olga Kalinina $^{1 *}$, Anastasia Levina ${ }^{1}$ \\ ${ }^{1}$ Peter the Great St. Petersburg Polytechnic University, Institute of Industrial management, Economy \\ and Trade, 195251, Polytechnicheskaya, 29, St.Petersburg, Russia
}

\begin{abstract}
The paper is devoted to the current and debatable problem of methodology of choosing the effective innovative enterprises for venture financing. A two-stage system of commercial innovation evaluation based on the UNIDO methodology is proposed. Engineering systems account for 25 to $40 \%$ of the cost of high-rise residential buildings. This proportion increases with the use of new construction technologies. Analysis of the construction market in Russia showed that the production of internal engineering systems elements based on innovative technologies has a growth trend. The production of simple elements is organized in small enterprises on the basis of new technologies. The most attractive for development is the use of venture financing of small innovative business. To improve the efficiency of these operations, the paper proposes a methodology for a two-stage evaluation of small business development projects. A two-stage system of commercial evaluation of innovative projects allows creating an information base for informed and coordinated decision-making on venture financing of enterprises that produce engineering systems elements for the construction business.
\end{abstract}

\section{Introduction}

Internal engineering systems and networks are the basis of the infrastructure of any construction site. Elements of these systems include units and blocks of sewerage systems, heating and power supply, automatic water fire extinguishing installations, fire water supply, details of "smart houses" and so on. The cost of construction is largely determined by the technical characteristics and cost of these elements.

Details and blocks of engineering systems are produced in small enterprises, as well as in divisions of medium and large companies in the construction business. There is a high level of competition, new production technologies and innovative projects of products with improved operational characteristics are actively developing.

Financing of development of such enterprises is most expedient due to venture business. At present, it is considered that venture business is one of the most effective ways of financing innovative projects. Venture funds invest in little-known, promising innovative organizations

*Corresponding author: olgakalinina@bk.ru 
at its earliest stages of development, when it is unknown and has not yet completed the implementation of the "business idea" underlying its business. The investment period is from three to seven years. Venture fund in exchange for its investments receives a stake in the authorized capital of an innovative enterprise and after a certain period of time comes out of it by "buyback": it sells its stake in the open market or to a strategic investor. [1-9]

Some of these projects are unprofitable or low-profitable, but some of them bring significant profits and even over-profit. In this regard, the average rate of return of venture funds is about $25-30 \%$, which significantly exceeds the incomes of conventional investment projects with an indicator of $5-10 \%$.

In Russia, venture funds appeared in the early 90's. Restructuring of the economy and privatization processes have caused a sharp increase in interest in the market of direct investment in Russia from various investors and, as a result, reflected in the more than dynamic start of the venture business. This activity is supported by some large companies, and venture funds and innovation development networks are being created [1-4, 7-10]. The main tasks of these organizations are to search for new effective ideas - innovations and create conditions for their transformation into highly profitable commercial enterprises.

The most common mechanism for venture financing of business is the system of organizing a joint venture with a "buyback". To implement this methodology, it is necessary to find a prospective enterprise - "start-up", determine its real value, the amount of the authorized capital, the value of the joint venture at the beginning of financing and at the time of the agreed redemption period. At the stage of choosing effective "start-ups" dozens and hundreds of proposals are eliminated. At the same time, venture investors often use their own expert assessments $[7,8]$. It is at this stage that most of the disagreements between investors and the founders of the company arise, and at this stage a significant part of the deals is broken. The literature suggests a sufficiently large number of methods for assessing the effectiveness of innovation projects and calculating the company's value at various stages of development [11-15]. Many methods are rather complicated and require initial information, which at the stage of "start-up" can not be sufficiently reliable.

The article proposes a technique for a two-stage commercial evaluation of innovative projects at the "start-up" stage. The methodology is intended for use in the process of joint venture fund operation and an innovative enterprise (due diligence). It involves the evaluation of an innovative project from two sides: from the economic efficiency of the project as a whole and from the financial situation and the level of risks of the manufacturer. The proposed methodology is based on UNIDO methodology [16] and allows, first of all, to more rationally approach the choice of an innovative enterprise for financing from a venture fund. The second most important issue that allows us to solve the two-stage method of calculating economic and financial indicators is the possibility of creating the initial information for calculating the company's value at various stages of its development, including, at the time of the "redemption".

\section{Methods}

Venture financing is a long-term direct investment in small innovative enterprises with a high or relatively high level of risk in order to generate significant profits in the period from 3 to 7 years. There are external and internal venture business. The development of domestic venture business is most often carried out in large corporations at the expense of the resources of the initiators of the idea. Financing external ventures is by raising funds from external sources: investment, insurance, charitable, pension funds, state resources, private investors. Organizationally, this is done either through the creation of venture funds or through the individual activities of entrepreneurs, called business angels. At the same time, if you do not go into the sectoral details, three types of financing objects have become most widespread: 
applied research (the stage of "sowing" according to the US-European classification of the stages of innovation development), start-ups in the same classification and small innovative enterprises with a lack of financial resources. The main types of external venture business are presented in Fig. 1.

\section{External Venture Business}

Private investors (business angels)

Specialized companies (venture funds)

$\begin{array}{ccc}\text { Business idea } & \begin{array}{c}\text { Completed research } \\ \text { ("start-up phase) }\end{array} & \begin{array}{c}\text { A small enterprise with a deficit of } \\ \text { finance and qualified personnel }\end{array}\end{array}$

Fig. 1. The enlarged scheme of varieties of external venture business, compiled by the authors

Venture investments for decision-making on financing require a feasibility study. Two main points must be taken into account. The first is the availability of information for planned calculations, which is quite different for such, for example, financing objects as "sowing" or operating a small enterprise. And the second is the rules for making decisions about financing from venture funds, industrial companies or business angels. If a business angel - a private investor decides to participate in innovative projects mainly on the basis of his own experience and risk assessment [8], venture funds have specially developed standards for selecting projects for investment. In this paper, the methodology for assessing the effectiveness of future investments only for venture funds is considered.

The proposed system of settlements is aimed at ensuring their effective development, creating conditions for operational management and decision-making at various stages of development. It should be noted that the literature offers a lot of classifications of stages and stages of development of innovative projects [11,12,13].

Here, the authors maintain a classification that includes 4 stages:

- preparation for the opening of the enterprise, initial financing and organizational development (start-up),

- rapid initial growth in sales volumes, significant investment in production, possible negative cash flow,

- achievement of significant economic results, financial payback, positive cash flow,

- a decrease in revenues as a result of increased competition, the search for new ideas and options for the development of the company, possible negative cash flow.

For effective implementation of the project, a specific system of financial and economic calculations is appropriate at each stage.

The first is a feasibility study based on a methodology for commercial project evaluation, and the development of a business plan. On the second - a regular assessment of the financial condition of the enterprise and monitoring the implementation of financial and economic indicators of the business plan. The third is to monitor the financial condition of the company and determine the value of the enterprise to prepare for the transition to the fourth stage. On the fourth - again, the valuation of the company, the development of new ideas and business planning. To effectively manage projects and make rational decisions, a correlation between calculation methods and decision criteria at each stage is necessary (Table 1).

The basis for making initial decisions on the project is its feasibility study and the development of a business plan. The business plan is a clearly structured by sections section of the work and operations necessary for the implementation of the project. At the same time, a project is understood as a plan for investing money and capital in order to achieve previously planned benefits.

The main objective of developing a business plan is to justify the costs of the project and, accordingly, the rationale for the sources of its financing. The business plan is one of the main documents in their general list for presentation to investors and creditors. Initially, the 
development of business plans was carried out only with respect to investment projects. Accordingly, for all works and operations included in this document, costs and results incomes should be justified and calculated.

Table 1. Stages of the project and methods of financial and economic calculations.

\begin{tabular}{|c|l|l|}
\hline Stages of multi-project & $\begin{array}{l}\text { Basic methods of financial and economic } \\
\text { calculations }\end{array}$ & Decision Criteria \\
\hline $\begin{array}{l}\text { Preparation for the opening of } \\
\text { the enterprise, initial financing }\end{array}$ & $\begin{array}{l}\text { Feasibility study and business plan } \\
\text { development }\end{array}$ & $\begin{array}{l}\text { Net present value, } \\
\text { profitability and } \\
\text { operating leverage }\end{array}$ \\
\hline $\begin{array}{l}\text { Rapid initial growth in sales, } \\
\text { possible negative cash flow }\end{array}$ & $\begin{array}{l}\text { Regular assessment of the financial } \\
\text { condition of the enterprise and control } \\
\text { over the implementation of business plan } \\
\text { indicators }\end{array}$ & $\begin{array}{l}\text { Special system of } \\
\text { financial indicators }\end{array}$ \\
\hline $\begin{array}{l}\text { Financial payback, positive cash } \\
\text { flow }\end{array}$ & $\begin{array}{l}\text { Monitoring the financial condition of the } \\
\text { company and determining the value of the } \\
\text { company }\end{array}$ & $\begin{array}{l}\text { System of financial } \\
\text { indicators, company } \\
\text { value }\end{array}$ \\
\hline $\begin{array}{l}\text { The aggravation of competition, } \\
\text { the search for new ideas and } \\
\text { options for development }\end{array}$ & $\begin{array}{l}\text { Again, valuing the company, developing } \\
\text { new ideas and business planning }\end{array}$ & $\begin{array}{l}\text { The company's value, } \\
\text { profitability and } \\
\text { operating leverage }\end{array}$ \\
\hline
\end{tabular}

These calculations are information for decision-making by investors or creditors: to finance the project or to refuse financing. The decision on financing is made on the basis of the size of such characteristics as the payback period and the simple rate of return for the project, as well as discounted indicators, the net present value of NPV and the internal rate of return of the IRR.

With the development of business planning, this system of calculations showed significant shortcomings associated with the fact that the above decision criteria are not included in the indicators characterizing the effectiveness of enterprises.

The financial condition of the enterprise and the effectiveness of its development is characterized by a system of indicators of business activity and financial stability. The most important characteristics here are the profitability of sales, profitability of assets and equity, as well as such characteristics of financial stability as the share of equity in assets, financial leverage (lever), the coefficients of general and urgent liquidity, solvency ratios. For effective project management, it becomes necessary to combine these project-specific and enterprisewide evaluations into one business planning system.

Based on research and numerous calculations by the authors, it is recommended to follow the two approaches in the economic evaluation of innovative projects:

- two-stage system of financial and economic calculations for investment projects;

- one-stage settlement system for operational projects.

The methodology proposed by the authors for evaluating innovative projects for the production of engineering systems for a high-rise construction business is based on the first approach and includes a two-stage calculation system [14]:

- stage 1- determination of commercial efficiency on the basis of payback calculations and discounted indicators;

- stage 2 - study of the impact of project implementation on the growth of the company's profits and labor productivity, profitability indicators and level of operational (operational) risks.

Below is a list of the main financial and economic indicators for describing the planned results at both stages of the project evaluation. 
Stage 1. Definition of economic efficiency on the basis of calculations of a recoupment and the discounted indicators;

INDICATORS

- Payback period of investments $r$

- Simple rate of return on investment $\mathrm{i}$

- Net present value of NPV

- Internal rate of return IRR

Stage 2. Study of the impact of project implementation on the growth of the company's profits and labor productivity, profitability and level of operational risks.

INDICATORS

- Profit increase from sales at the enterprise

- Increase in labor productivity (sales per employee per month)

- Profitability of sales of ROS

- Operational (production) leverage of ODA

It should be noted that the list of indicators for the second stage can be significantly expanded in accordance with the features of each company implementing an innovative project and considered as an object of venture financing. The choice of additional indicators is based on the methodology of financial diagnostics of enterprises, developed by the authors within the system of economic and financial calculations for innovative projects. [14].

In this presentation, business planning at the first stage of the innovation project allows solving two main tasks:

- provide a business case for the venture financing of an innovative project,

- to create an information base for planning the development of a new enterprise, calculating its initial value and the future value of the "buyback", taking into account the quantitative assessment of the existing financial and production risks.

\section{Results}

The income of venture companies is formed due to the system of "buyback", i.e. sale of the share of the venture company in a joint innovation enterprise after its release in 3-7 years of operation. To forecast the value of this income, it is necessary to determine the value of the applicant's company, the amount of the authorized capital, the cost of the joint venture at the beginning of financing and at the time of the agreed repurchase period. A two-stage system of commercial evaluation of innovative projects allows creating an information base for determining the value of an innovative enterprise. We will dwell in more detail on the methodology for estimating the value of the company, which is necessary at the third and fourth stages of the implementation of innovative projects for the production of engineering systems for construction (Table 1).

In accordance with the two-stage settlement system, the authors propose a set of relatively simple evaluation methods that are based on the results of the second stage of calculations and logically fit into the overall system of financial and economic calculations of the planned innovation enterprise. The theory of business valuation offers three approaches to solve this problem: costly, profitable and comparative. The author's methodology suggests estimating the company's value based on various development options and the results of the company's financial diagnostics in the second and third stages of development.

To determine the initial value of the company at the third stage of the innovation project implementation, it is necessary to consider at least two development options:

- the first one - without additional investment of the project; here it is supposed to be further implemented in accordance with the indicators of the previously developed business plan with a two-stage commercial evaluation system, 
- The second is to attract investments in accordance with the leadership strategy; here in the near future, competition, commercial and financial risks are expected to grow, and the prices for company services will decline.

For both variants of development, the company's value at the time of Stom's assessment is determined on the basis of a cost approach, after conducting an audit and diagnosing the financial condition of the operating enterprise. To expand the information on the value of the enterprise at the time of valuation, it is also necessary to use the income approach methods: "profit capitalization", "50\% of sales" and "fivefold profit from sales." If there is information about the purchase and sale of similar enterprises, it will significantly supplement the information on the company's value. Based on the agreement of the results obtained, the actual value.

St Mo F this characteristic is the basis for further calculations of the company's value in the planned period of time. Table 2 shows the results of the valuation of the innovative enterprise implementing the project for the production of elements and units for the equipment assembly in the construction business.

Table 2. Results of the initial valuation of the company at the third stage of the multi-project implementation

\begin{tabular}{lc}
\hline Company valuation method & Sum, mio RUR \\
\hline Cost & 14,0 \\
Capitalization of profit & 11,0 \\
"50\% of sales" & 14,5 \\
"Fivefold profit on sales, & 16,0 \\
\hline Approved St Mo F & 13,5 \\
\hline The value of the company after investing in assets, taking into & \\
account the appreciation factor St In & 18,0 \\
\hline
\end{tabular}

After determining the actual value of the company at the time of valuation, it is necessary to establish a planned period for calculating changes in the value of the company. Its magnitude depends on the specifics of the project, but should not exceed three years.

For the second variant of development it is necessary to determine the company's value at the planned moment of attracting additional investments St in. Here, the rise in the cost of the enterprise due to the attraction of additional capital should be taken into account. When determining the coefficient of appreciation, the key factors are the turnover of the assets of the enterprise (the number of assets turnover per year), and the profitability of ROA assets. These are the indicators determined at the 2 nd stage of the commercial evaluation of the innovation project. After the establishment of the St in, one can proceed to the calculation of the company's value for the anticipated planning period. Here you can apply several methods of evaluation. In the author's methodology, a venture approach and a method of future value are recommended. Thus, the two-stage system of commercial project appraisal allows creating an information base for clarifying and coordinating the actual and planned cost of the enterprise, adjusting the project implementation process, solving organizational, production and financial issues.

\section{Discussion}

The most difficult issues for the venture business are the procedure for selecting innovations for financing and evaluating the company's future value for "buyback". The effective organization of this process involves accelerated screenings and presentation to fund the best and most promising ideas.

The system of "buyback" is realized through three main methods: 
- Management buy-out (sale of the share of the venture company to existing shareholders and management);

- external redemption (sale of a share of a venture company to an outside investor);

- sale of the share of the venture company through the public offering of IPO shares.

The literature suggests and uses a large number of methods and approaches to determine the value of a company and attract venture investors [6-7]. The task is to systematize these methods in relation to different stages of venture financing and, most importantly, in relation to different levels of innovation. Radical innovations associated with new products in the whole world or in Russia, and processes, are more risky and, accordingly, their results are more difficult to predict. For such innovations, it is advisable to conduct planned calculations of cost indicators on the basis of simple aggregated methods.

For simple innovations related to significant, and sometimes, and with minor changes in known processes and products, more detailed methods can be used. Most innovations in the field of engineering systems for high-storey construction are just such. In accordance with this, it can be reasonably recommended to apply the two-stage system of commercial evaluation of innovative projects for the organization of venture financing in the construction business.

In the process of this work, a revised and agreed business plan for the development of the joint venture should be developed, on the basis of which further sources of financing, order and price of the buyback are determined. The main task of the two-stage feasibility study and analysis of the company's value is precisely to achieve this consent.

\section{Conclusions}

1. Two-stage system of commercial evaluation of innovative projects allows creating an information base for informed and coordinated decision-making on venture financing of enterprises that produce elements of engineering systems for the construction business.

2. Based on the results of the calculation of indicators for the second stage of the commercial evaluation, financial diagnostics and valuation of the company for the entire planned period of its development are carried out. This creates a fairly broad base of financial and economic indicators for agreeing and clarifying operational plans for further implementation of the venture financing of the project.

3. Relatively simple algorithms recommended by the authors of the calculation methods and available software products allow you to concentrate when monitoring the development of the project to ensure the reliability of the original data.

\section{References}

1. URL: http://www.rusventure.ru/ru/programm/analytics (13.03.2017)

2. Popov, P. Roosenboom, Journal on Banking and Finance, 37, Issue 12, 4695-4710 (2013)

3. J.L. Woolley, A.V. Bruno, E.D. Carlson, Journal of Management for Global Sustainability, 2, 7-30 (2013)

4. J.P. Killing, Strategies for Joint Venture Success. Routledge Library Editions: International Business, 22, 132 (2013)

5. E.M. Rogova, M.A. Sapozhnikova, Problems of Value Russian Innovative Companies Evaluation at Early Stages of Development by Venture Investors. Scientific and technical sheets of the St.-Petersburg State Polytechnic university. Economic sciences, 6-1 (185), 150-158 (2013) 
6. L.V. Nikolova, J.J. Kuporov, D.G. Rodionov, International Journal of Economics and Financial Issues, 5 (3S), 68-72 (2015)

7. A.O. Adamtsevich, A.P. Pustovgar, S.A. Pashkevich, A.V. Eremin, International Journal of Applied Engineering Research, Vol. 11, pp. 1609 - 1611 (2016)

8. V. Kankhva, IOP Conference Series: Earth and Environmental Science, Vol 90, 012175 (2017) DOI - 10.1088/1755-1315/90/1/012175

9. G. Gogoberidze et al, Indicator method of estimation of human impact assessment for coastal local municipalities. Measuring and Modeling of Multi-Scale Interactions in the Marine Environment - IEEE/OES Baltic International Symposium, BALTIC 2014. 6887840

10. A.V. Kozlov, E.V. Rytova, et al, The valuing of the indicator of a regional industrial development: The fuzzy logic approach. Proceedings of the 19th International Conference on Soft Computing and Measurements, SCM 2016. Paper number 7519842, 545-547 (2016)

11. Rice, A. L. (Ed.). (2013). The enterprise and its environment: A system theory of management organization (Vol. 10). Routledge.

12. A.B. Anisiforov, A.S. Dubgorn, Organization of enterprise architecture information monitoring. Proc. of the 29th IBIMA Conf. - Education Excellence and Innovation Management through Vision 2020: From Regional Development Sustainability to Global Economic Growth, pp 2920-2930 (2017)

13. V. Berens, P.M. Havranek, Guidelines for assessing the effectiveness of investments: translate Engl. (Moscow, Interexpert, Infra-M, 1995)

14. A. Pustovgar, L.A. Shilova, A.O. Adamtsevich, L.A. Shilov, International Journal of Applied Engineering Research, Vol. 10, pp. 40988 - 40990 (2015)

15. V. Izotov, O. V. Rostova, Development of a system of sectoral investment priorities, Proc. of the 29th IBIMA Conference - Sustainable Economic Growth, Education Excellence, and Innovation Management through Vision 2020. Pp. 1812-1822. 